\title{
Farm-scale evaluation of two widely used sanitation practices for reducing primary inoculums of apple scab in organic apple production
}

\author{
Holb, I.J., Rózsa, A. \& Abonyi, F. \\ University of Debrecen, P.O. Box 36, H-4015 Debrecen, Hungary (e-mail: holb@agr.unideb.hu)
}

\begin{abstract}
Summary: Effects of two widely used sanitation practices were evaluated at farm-scale level on leaf degradation and primary infection by Venturia inaequalis in an organic apple orchard (Eperjeske) on two apple cultivars (Jonathan and Prima) from 2011 to 2013. The tested sanitation practices were eradication of fallen leaves by collection and disc cultivation. Treatments of eradication of fallen leaves by collection and disc cultivation reduced significantly $(\mathrm{P}<0.001)$ leaf litter density with 70-85 and $40-55 \%$, respectively, compared to untreated plots in both years. Above treatments in the same order reduced spring scab incidence with 40-50, and 10-20\%, respectively, compared to untreated plots. Incidence of leaf scab in autumn was not significantly lower $(\mathrm{P}<0.05)$ in the treatments in the years.
\end{abstract}

Key words: leaf litter density, Venturia inaequalis, spring disease incidence, Malus x domestica Bork.

\section{Introduction}

Success of diseases management in an organic orchard is highly dependent upon control strategy made during the primary infection season (MacHardy, 1996, Holb, 2002). High disease pressure, favourable weather condition and scab-susceptible cultivars support the buildup of severe scab epidemics in these orchards. As approved fungicides against apple scab is not effective enough in organic apple production, scab-resistant or moderately scab-susceptible cultivars are suggested to be planted and efforts to reduce primary inoculum sources are highly appreciated (MacHardy, 1996; Ellis et al., 1998; Holb \& Heijne, 2001; Holb et al., 2003). Apple scab fungus survives on fallen leaves on the orchard floor; therefore, eradication leaf litter from the orchard floor seems to be an effective control method (Curtis, 1924). Only non-chemical sanitation practices can be used as eradication methods in organic orchards (Anonymous, 1989; Holb, 2005); therefore, possible non-chemical and simple sanitation practices are eradication of fallen leaves by collection, burning, disc cultivation, ploughing, shredding or applying antagonists. In early studies (Curtis, 1924, Keitt, 1936; Louw, 1948), it was demonstrated that if burning, ploughing or collection of fallen leaves were used separatelly, primary inoculum source in the following year could be reduced with 40-70\%. Leaf shredding have been investigated from the 1990th (Sutton \& MacHardy, 1993; Sutton et al., 2000; Vincent et al., 2004) and it was shown that leaf shredding resulted in a reduction of 40 to $95 \%$ and 45 to $85 \%$ in ascospore inoculum and in scab incidence next spring, respectively. Studies from the USA and Canada (Heye \& Andrews, 1983; Vincent et al., 2004) showed that the most effective fungal antagonists were Athelia bombacina and Microsphaeropsis ochracea, with reduction in ascospore production of $70-85 \%$, however, commercial bioproduct is still not available. In the Netherlands, covering of orchard floor with plastic foil, as an leaf litter eradication method, was used in integrated apple orchards which resulted in $85-95 \%$ leaf scab incidences in spring (Holb et al., 2004ab). Simple sanitation practices have been widely investigated; however, they have not been compared to each other in one orchard system and no information is available about their effects on scab infection risk in organic apple orchards.

The aim of the present study was to evaluate the effect of two sanitation practices (eradication of fallen leaves by collection and disc cultivation) on leaf degradation and primary infection by Venturia inaequalis in an organic apple orchard on two apple cultivars. A raw economic evaluation was also made for farm-scale level to evaluate the effectiveness of the two sanitation practices.

\section{Materials and methods}

\section{Orchards and plant materials}

The study was carried out in two organic apple orchards at Eperjeske in Eastern-Hungary in 2011 and 2003. All trees were on M.26 and M.9 rootstocks and pruned to a spindle shape. Bare soil has been maintained in the rows and grass 
has been grown in the spacings between rows since the planting of the orchards. Trees were placed with a between-row spacing of $5 \mathrm{~m}$, and a within-row spacing of $2 \mathrm{~m}$ in both orchards. Observations were made on a moderately susceptible apple cultivar (Jonathan and Prima). Trees were grown according to the Hungarian Organic Guidelines derived from international IFOAM standards (Anonymous, 1989; Holb, 2005).

Leaf wetness and temperature were recorded with a digital hygrothermograph (Techno Ltd., Budapest, Hungary) from 1 March until 31 May in 2012 and 2013. Potential infection periods, based on the criteria of Mills \& La Plante (1951), were calculated from the temperature and leaf wetness data.

\section{Treatments}

Three sanitation treatments were prepared in four replicates of each treatment in the autumns of 2011 and 2012. The size of the experimental units was 1.5 ha. Treatments were prepared after leaf fall as follows: 1) collecting of fallen leaves in autumn; 2) destroying fallen leaves by disc cultivation in autumn, and 3 untreated control. Leaf collecting was done with John Deere F-725 flail mower (Deere \& Company, Moline, Illinois, USA) applying and not applying a leaf collector box, respectively, on 22 November 2011 and 8 November 2012, after defoliation. Disc cultivation was 25 November 2011 and 14 November 2012.

\section{Assessments of leaf degradation}

Leaf litter density (LLD) was assessed in autumn on 28 November 2011 and 29 November 2012 and in spring on 22 April 2012 and 11 April 2013. Both in autumn and spring, leaf litter density assessment was made by measuring the area of fallen leaves per $\mathrm{m}^{2}$ area of orchard floor. Presented LLD data of each treatment were expressed as the proportion of LLD data of the untreated plots. Consequently, autumn and spring LLD values in the untreated plots of each location were considered to be $100 \%$. In this way, percent LLD reduction of each treatment was presented compared to untreated plots.

\section{Assessments of disease incidence}

In both locations, scab assessments were made on leaves in autumn and the following spring. Scab incidence in autumn was assessed on six trees in each experimental unit on 24 October 2011, and 26 October 2012. Scab incidence in spring was assessed after the incubation period of the fourth Mills infection period at the end of May in each year and location. Both in autumn and spring, 200 leaves per tree were assessed. Disease incidence was calculated as the percentage of leaves diseased.

\section{Statistical analyses}

All data sets were subjected to analysis of variance (ANOVA) using the Genstat 5 Release 4.1 statistical package
(Lawes Agricultural Trust, IACR, Rothamsted, UK). All data were transformed to angular $\left(\mathrm{Y}=\operatorname{arcsine}[\%]^{1 / 2}\right)$ to correct normality before analysis. Significant F-tests were followed by a Least Significance Difference (LSD)-test for comparing the means of the treatment means for all measurements in each year.

\section{Results}

\section{Leaf incidence in autumn}

Leaf incidence in autumn 2011-2012 was ranged between 25 and $29 \%$ on cv. Jonathan and between 3 and $5 \%$ on cv. Prima among treatments (Table 1). Lower incidence values on cv. Prima are due to scab-resistance compared to cv. Jonathan. Leaf incidence was not significantly different $(\mathrm{P}<$ 0.05 ) in the treatments. Similar leaf incidence was observed in autumn of 2013 (data not shown).

Table 1. Scab incidence (\%) in autumn in three sanitation treatments at farm-scale level on cv. Jonathan and Prima at Eperjeske in 2011 and 2012.

\begin{tabular}{|l|c|c|c|c|c|c|c|c|}
\hline & \multicolumn{6}{|c|}{ Scab incidence } \\
\cline { 2 - 10 } & \multicolumn{6}{|c|}{ Jonathan } & \multicolumn{2}{c|}{ Prima } \\
\hline \multicolumn{1}{|c|}{ Treatments $^{\mathrm{a}}$} & \multicolumn{2}{|c|}{2011} & 2012 & \multicolumn{2}{c|}{2011} & \multicolumn{2}{c|}{2012} \\
\hline Untreated $^{2} 28.5$ & $\mathrm{a}^{\mathrm{b}}$ & 29.5 & $\mathrm{a}$ & 4.8 & $\mathrm{a}$ & 4.5 & $\mathrm{a}$ \\
\hline Collection & 27.8 & $\mathrm{a}$ & 28.3 & $\mathrm{a}$ & 3.5 & $\mathrm{a}$ & 4.7 & $\mathrm{a}$ \\
\hline Disc cultivation $^{2}$ & 25.2 & $\mathrm{a}$ & 29.5 & $\mathrm{a}$ & 5.2 & $\mathrm{a}$ & 4.5 & $\mathrm{a}$ \\
\hline F-test $^{\mathrm{c}}$ & \multicolumn{3}{|c|}{$\mathrm{ns}$} & \multicolumn{3}{c|}{$\mathrm{ns}$} & \multicolumn{3}{c|}{$\mathrm{ns}$} & \multicolumn{2}{c|}{$\mathrm{ns}$} \\
\hline
\end{tabular}

${ }^{\text {a }}$ Collection = collecting of fallen leaves in autumn; Disc cultivation = destroying fallen leaves by disc cultivation in autumn.

${ }^{\mathrm{b}}$ Mean values within columns followed by different letters are significantly different.

${ }^{\mathrm{c}}$ F-test $=$ ns not significant. Because of the back-transformation on scab incidence data set, no LSD and SED values are available.

\section{Leaf litter density in autumn and spring}

Sanitation practices reduced considerably leaf litter density compared to untreated plots in both years (Table 2). The effect of leaf litter reduction was similar in both cultivars. The highest sanitation was achieved by leaf collection $\mathrm{n}$ both autumn and spring. According to the results obtained from the two years and locations, treatments of destroying leaves by disc cultivation significantly $(\mathrm{P}<0.001)$ leaf litter similarly with $40-55 \%$ compared to untreated plots. Reduction by treatments of leaf collection with plastic foil was also significant $(\mathrm{P}<0.001 ; 70-85 \%)$ compared to untreated plots.

\section{Leaf incidence in spring}

Sanitation practices reduced significantly scab incidence in the primary infection periods after the incubation period 
of the fourth Mills infection period (Table 3). The highest leaf incidence was observed in the untreated plots (12.9 and $15.4 \%$ on cv. Jonathan and 24.5 and $22.6 \%$ on cv. Prima in 2012 and 2013, respectively). Reduction on scab incidence was significant $(\mathrm{P}<0.01)$ in the treatments of leaf collecting compared to untreated plots. Treatments of destroying leaves by disc cultivation and collection reduced scab incidence with $10-20$ and $40-50 \%$, respectively, compared to untreated plots.

Table 2. Effect of three sanitation treatments on leaf litter density (LLD) in autumn and spring at farm-scale level on cv. Jonathan and cv. Elstar at Eperjeske in 2011-2013.

\begin{tabular}{|c|c|c|c|c|c|c|c|c|}
\hline & \multicolumn{8}{|c|}{$\operatorname{LLD}(\%)^{\mathrm{a}}$} \\
\hline & \multicolumn{4}{|c|}{ Autumn } & \multicolumn{4}{|c|}{ Spring } \\
\hline Treatments $^{\mathrm{b}}$ & \multicolumn{2}{|c|}{2011} & \multicolumn{2}{|c|}{2012} & \multicolumn{2}{|c|}{2012} & \multicolumn{2}{|c|}{2013} \\
\hline \multicolumn{9}{|l|}{ Jonathan } \\
\hline Untreated & 100 & $a^{c}$ & 100 & $\mathrm{a}$ & 100 & $\mathrm{a}$ & 100 & $\mathrm{a}$ \\
\hline Collection & 19.2 & $\mathrm{~b}$ & 15.5 & $\mathrm{~b}$ & 28.4 & $\mathrm{~b}$ & 26.6 & $\mathrm{~b}$ \\
\hline Disc cultivation & 54.7 & $\mathrm{c}$ & 59.3 & $\mathrm{c}$ & 51.8 & $\mathrm{c}$ & 53.8 & $\mathrm{c}$ \\
\hline F-test ${ }^{d}$ & \multicolumn{2}{|c|}{ *** } & \multicolumn{2}{|c|}{$* * *$} & \multicolumn{2}{|c|}{$* * *$} & \multicolumn{2}{|c|}{$* * *$} \\
\hline \multicolumn{9}{|l|}{ Prima } \\
\hline Untreated & 100 & $\mathrm{a}$ & 100 & $\mathrm{a}$ & 100 & $\mathrm{a}$ & 100 & $\mathrm{a}$ \\
\hline Collection & 22.6 & $\mathrm{~b}$ & 25.1 & $\mathrm{~b}$ & 33.5 & $\mathrm{~b}$ & 29.6 & $\mathrm{~b}$ \\
\hline Disc cultivation & 51.7 & $\mathrm{c}$ & 55.6 & $\mathrm{c}$ & 45.2 & $\mathrm{c}$ & 49.3 & $\mathrm{c}$ \\
\hline F-test & \multicolumn{2}{|c|}{ *** } & \multicolumn{2}{|c|}{$* * *$} & \multicolumn{2}{|c|}{ **: } & \multicolumn{2}{|c|}{$* * *$} \\
\hline
\end{tabular}

${ }^{a}$ Data of untreated plots were considered to be $100 \%$. Presented LLD data were expressed as the proportion of LLD data of the untreated plots.

${ }^{\mathrm{b}}$ Collection $=$ collecting of fallen leaves in autumn; Disc cultivation $=$ destroying fallen leaves by disc cultivation in autumn.

${ }^{c}$ Mean values within columns followed by different letters are significantly different.

${ }^{\mathrm{d}} \mathrm{F}$-test $=* * *$ significant at $\mathrm{P} \leq 0.001$. Because of the back-transformation on scab incidence data set, no LSD and SED values are available.

Table 3. Scab incidence (\%) in spring in three sanitation treatments at farm-scale level on cv. Jonathan and on cv. Prima at Eperjeske in 2012 and 2013.

\begin{tabular}{|l|c|c|c|c|c|c|c|c|c|}
\hline & \multicolumn{6}{|c|}{ Scab incidence in spring $^{\mathrm{a}}$} \\
\cline { 2 - 10 } & \multicolumn{3}{|c|}{ Jonathan } & \multicolumn{5}{c|}{ Prima } \\
\hline Treatments & \multicolumn{2}{|c|}{2012} & \multicolumn{2}{|c|}{2013} & \multicolumn{2}{c|}{2012} & 2013 \\
\hline Untreated & 11.9 & $\mathrm{~b}^{\mathrm{c}}$ & 13.2 & $\mathrm{~b}$ & 2.5 & $\mathrm{~b}$ & 2.6 & $\mathrm{~b}$ \\
\hline Collection & 7.4 & $\mathrm{a}$ & 9.6 & $\mathrm{a}$ & 1.7 & $\mathrm{a}$ & 1.8 & $\mathrm{a}$ \\
\hline Disc cultivation & 9.9 & $\mathrm{ab}$ & 11.3 & $\mathrm{ab}$ & 2.3 & $\mathrm{ab}$ & 2.1 & $\mathrm{ab}$ \\
\hline F-test $^{\mathrm{d}}$ & \multicolumn{3}{|c|}{$* *$} & \multicolumn{3}{c|}{$* *$} & \multicolumn{3}{c|}{$*$} \\
\hline
\end{tabular}

${ }^{a}$ Scab incidence in spring was assessed after the incubation period of the fourth Mills infection period at the end of May.

${ }^{\mathrm{b}}$ Collection = collecting of fallen leaves in autumn; Disc cultivation $=$ destroying fallen leaves by disc cultivation in autumn;.

${ }^{c}$ Mean values within columns followed by different letters are significantly different.

${ }^{\mathrm{d}} \mathrm{F}$-test $=*$ and $* *$ significant at $\mathrm{P} \leq 0.05$ and $\mathrm{P} \leq 0.01$. Because of the backtransformation on scab incidence data set, no LSD and SED values are available.

\section{Raw economic evaluation of the two sanitation treatments}

Raw economic evaluation for both years and for both cultivars showed that disc cultivation is used for general agrotechnological purpose in orchards without grass alleys; and therefore, it gave no additional costs to the production technology. On the other hand, it did not reduce significantly scab incidence therefore spray costs were not changed (data not shown). In case of leaf collection, additional costs arose due to application of this sanitation practice but it also reduced scab incidence significantly which may results in less sprays and a consequent less spray cost (data not shown).

\section{Acknowledgements}

This research was supported partly by a grant of the Hungarian Scientific Research Fund (OTKA K108333), EU7 PURE programme and by the European Union and the State of Hungary, co-financed by the European Social Fund in the framework of TÁMOP-4.2.4.A/ 2-11/1-2012-0001 'National Excellence Program' under the project number: A2-SZJTOK-13-0061.

\section{References}

Anonymous (1989): Basic Standards for Organic Agriculture. Tholey-Theley Press, New York, New York. pp. 49.

Ellis, M. A., Ferree, D. C. \& Madden, L. V. (1998): Effects of an apple scab-resistant cultivar on use patterns of inorganic and organic fungicides and economics of disease control. Plant Dis. 82: 428-433.

Curtis, K. M. (1924): Black spot of apple and pear. New Zeel. J. Agron. 28: 21-28.

Heye, C. C. \& Andrews, J. H. (1983): Antagonism of Athelia bombacina and Chaetomium globosum to the apple scab pathogan, Venturia inaequalis. Phytopathology 73: 650-654.

Holb, I. J. (2002): Az ökológiai növényvédelmi technológia. (Organic plant protection.) [In: I. J. Holb (ed.): Az alma ventúriás varasodása: biológia, előrejelzés és védekezés.] (Apple Scab: Biology, Forecast and Control) Szaktudás Kiadó Ház, Budapest, pp. 319-323.

Holb I. J. (2005): Nemzetközi (IFOAM) növényvédelmi elöírások. (International (IFOAM) plant protection roles) [In. Holb I. (ed.) A Gyümölcsösök és a Szőlő Ökológiai Növényvédelme.] (Organic Plant Protection of Fruit Orchards and Grape) Mezőgazda Kiadó, Budapest, pp. 18-22.

Holb, I. J. \& Heijne, B. (2001): Evaluating primary scab control in organic apple production. Gartenbauwissenschaft 66: 254-261.

Holb, I. J., Jong, P. F., de \& Heijne, B. (2003): Efficacy and phytotoxicity of lime sulphur in organic apple production. Ann. Appl. Biol. 142: 225-233.

Holb, I. J., Heijne B. \& Jeger M. J. (2004a): Overwintering of conidia of Venturia inaequalis and the contribution to early epidemics of apple scab. Plant Dis. 88: 751-757. 
Holb, I. J., Heijne, B., Withagen, J. C. M. \& Jeger, M. J. (2004b): Spread of Venturia inaequalis from a defined source of ascospores into a disease-eradicated orchard section. J. Phytopathol. 152: 639646.

Keitt, G. W. (1936): Some problems and principles of orchard disease control with special reference to sanitation and related measures. J. Econ. Entomol. 29: 43-52.

Louw, A. J. (1948): Fusicladium of apples. IV. Can this disease stamped out? Farm. Suppl. Afr. J. 5: 28-32.

MacHardy, W. E. (1996): Apple Scab, Biology, Epidemiology and Management. APS Press. St. Paul, Minnesota, pp. 545.
Mills, W. D \& La Plante, A. A. (1951): Diseases and insects in the orchard. Corn. Ext. Bull. 711: 1-100.

Sutton, D. K. \& MacHardy, W. E. (1993): The reduction of ascosporic inoculum of Venturia inaequalis by orchard sanitation. Phytopathology 83: 247. (Abstract)

Sutton, D. K., MacHardy, W. E. \& Lord, W. G. (2000): Effect of shredding or treating apple leaf litter with urea on ascospore dose of Venturia inaequalis and disease buildup. Plant Dis. 84: 1319-1326.

Vincent, C., Rancourt, B. \& Carisse, O. (2004): Apple leaf shredding as a non-chemical tool to manage apple scab and spotted tentiform leafminer. Agric. Ecosyst. Environ. 104: 595-604. 